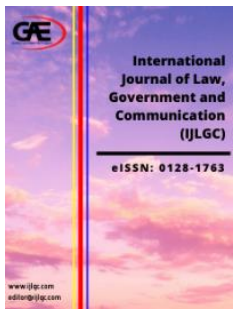

\author{
INTERNATIONAL JOURNAL OF LAW, \\ GOVERNMENT AND COMMUNICATION \\ (IJLGC) \\ www.ijlgc.com
}

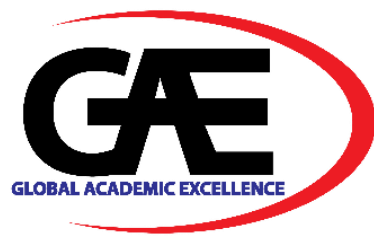

\title{
DISEASE BEARING INSECT RESEARCH IN MALAYA BY JAPANESE SCIENTISTS DURING WORLD WAR II AND ITS POSITION IN INTERNATIONAL LAW
}

\author{
Marina Abdul Majid ${ }^{1 *}$ \\ 1 Research Center for History, Politics and International Affairs, Faculty of Social Sciences and Humanities, National \\ University of Malaysia (UKM), Malaysia \\ Email: marina76@ukm.edu.my; marinamajid76@gmail.com \\ * Corresponding Author
}

\section{Article Info:}

Article history:

Received date: 04.10.2021

Revised date: 21.10 .2021

Accepted date: 10.11.2021

Published date: 01.12.2021

\section{To cite this document:}

Abdul Majid, M. (2021). Disease Bearing Insect Research In Malaya By Japanese Scientists During World War II And Its Position In International Law. International Journal of Law, Government and Communication, 6 (26), 69-89.

DOI: $10.35631 /$ IJLGC.626007.

This work is licensed under $\underline{\text { CC BY } 4.0}$

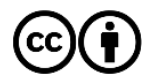

\begin{abstract}
:
Japanese scientists commissioned by the Imperial Japanese Navy (IJN) were tasked at the Nettai Igaku Kenkyusho or Institute of Medical Research (IMR) in Kuala Lumpur and other locations in Malaya during World War II (WWII) to identify cures for malaria, dengue, and scrub typhus rampant among Japanese troops in Southeast Asia. Such research on insects could contribute to biological warfare. This study identifies the background and destiny of these few Japanese scientists in Malaya conducting research on malaria, dengue and scrub typhus while evaluating if their research could have been an offense under international law at that point of time. A qualitative historical approach relying on documentation, soft law, treaties, and secondary resources obtained from archives and national libraries online from different countries and the Fold3-Historical Military Records website were referred. These documentations were classified according to names of Japanese scientists to form a short biography and to provide background information of the IMR during WWII. The results reveal some Japanese scientists responsible for malaria research at the IMR in Kuala Lumpur and Penang, and dengue research in Malaya, Singapore and Java. Human experimentation associated with dengue was suspected in Singapore. One IMR Japanese director had links with Unit 731. Kiyoshi Hayakawa, part of Unit 9420 in Singapore, Japan's subunit for its covert biological weapons programme conducted research on scrub typhus in Java and Malaya. These scientists continued as professors in Japan or were promoted to this position much later with one of them opening a medical company. Indeed, a gap existed in international law at the end of the 19th and early 20th century which failed to make experimentation illegal as a preparation stage rather than actual usage in warfare because of the omission to address the development, production and stockpiling of biological weapons.
\end{abstract}




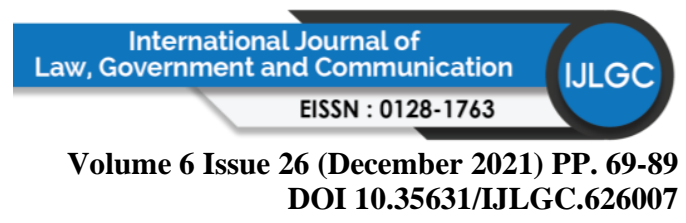

Keywords:

Malaya, Malaria, Dengue, Scrub Typhus, Institute Of Medical Research (IMR), Biological Warfare.

\section{Introduction}

Throughout World War II (WWII) in Malaya (presently known as Malaysia after its independence in 1957 and will be used interchangeably in this study) from the period of 19411945, Japan the occupying force had sent some of its scientists to this colonial territory to conduct research in identifying preventive measures and looking for a cure for malaria, dengue and to distinguish between scrub typhus and tsutsugamushi diseases caused by insects. Japanese troops who invaded Malaya, and other countries in Southeast Asia were very vulnerable to the said diseases given the tropical climate which made the anopheles mosquito causing malaria and aedes aegypti mosquito causing dengue and also the mites causing scrub typhus to thrive. Japanese troops relied on quinine to cure malaria as Japan controlled the supply of quinine with its invasion of Java, Indonesia but still its soldiers succumb to malaria (Iijima, 2016, p. 362).

Given the above scenario, Japan needed knowledgable microbiologist, parasitologist and entomologist ready to deal with malaria, dengue and scrub typhus when these maladies were brought back to Japan. By sending Japanese scientists to conduct research on these tropical diseases at Japan's occupied territories in Southeast Asia, this equipped them with experience to deal with these diseases in their home country. At the same time, this was for the furtherance of science since the cold climate in Japan was unconducive for the research on malaria and dengue which was more prevalent in the tropics. Moreover, this was a chance for Japanese scientists to venture into a new research area of tropical diseases that was least explored by them at that time to bring prestige to their country with some new findings.

Research on disease bearing insects in Japan was sponsored by the Imperial Japanese Army (IJA), the Imperial Japanese Navy (IJN) and its Ministry of Education which all had different projects of interest (Setoguchi, 2007, p. 176). Moreover, the National Research Council under Japan's Ministry of Education in 1943 had organised many research teams, some of which would study insect borne diseases which resulted with the recruitment of many parasitologist and entomologist to be deployed abroad to Japanese occupied territories (Setoguchi, 2007, p. 177).

Underlying the Japanese scientists' research on these tropical diseases mentioned was the Allied powers fear that there was a hidden agenda of utilizing insects for biological warfare against Japanese enemies. Biological warfare refers to "the use of any disease-causing organism or toxins found in nature as weapons of war with the intent to destroy an adversary" (St. Geogiev, 2009, p. 221). Mosquitoes causing malaria and dengue, and mites which causes scrub typhus can be used as vectors for diseases unleashed on humans in particular targeted areas during war time. Keener (2020, p. 2) indicates "[w]hen a nefarious actor uses insects as a delivery system, it is its own category of biological warfare called "entomological warfare"". Thus, the need to investigate if the nature of research by the Japanese scientists in Malaya could have led to covert biological warfare research that could be linked with Japan's famous Manshu Detachment 731 (in short Unit 731) based in Manchuria to arouse the suspicion of the Allied 


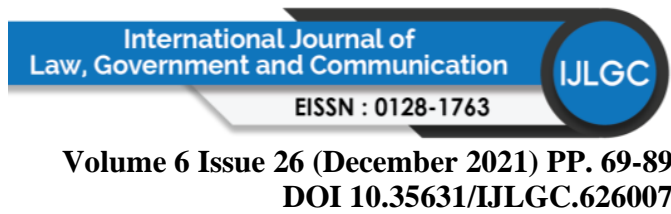

powers. Unit 731 also had a subunit in Singapore known as Unit 9420 (Harris, 2002, p. 76; Keiichi, 2010, p. 25). Moreover, the destiny of these Japanese scientists who conducted research on these tropical diseases mentioned will need to be investigated whether they survived the Pacific War to have illustrious careers in their home country or they could have perished. Simultaneously, there is also a need to examine international law at the end of the 19th and early 20th century whether the Japanese army's experimentation with malaria and dengue mosquitoes which does not involve large scale usage during warfare would have been an offense. With this background in mind, this study aims to identify the background and destiny of some of the Japanese scientists conducting research on malaria, dengue, and scrub typhus in Malaya during WWII while evaluating if their research could have been an offense under international law at that time.

\section{Literature Review}

Substantial literature written by various scholars (Fong, 2000; Galvin, 2003; Gold, 1997, Harris, 2002; Li, 1999, 2003; Tsuchiya, 2005) about Japan's testing and usage of biological weapons in China during WWII already exists. In comparison, little is known about Japan's biological warfare effort in Southeast Asia among countries such as Malaysia, Singapore, Thailand, Indonesia, and Burma as some scholars (Fong, 2000; Gold, 1997; Harris, 2002; Harris, 2003; Sidhu, 1991; Tsuchiya, 2005) have just mentioned these countries in scant passing without delving into further details on the Japanese activities in these countries. Lim (2020) has attempted to provide a more detailed account about Unit 9420, Japan's biological production facility in Singapore being housed at the King Edward VII Medical College during WWII and naming some Japanese medical scientists and army personnel involved when previous scholars have failed to provide a detailed account.

As for the case of Malaysia, scant literature currently exists about Japan's biological warfare effort namely in the writings by Majid (2017) which focused on the old Tampoi mental hospital in Johor and Tuanku Muhammad School in Kuala Pilah, Negeri Sembilan being the breeding ground for fleas and rats as the Japanese were cultivating plague to be sent to Thailand and henceforth to Burma during WWII. Apart from the states of Johor and Negeri Sembilan, Lim (2020) also mentions in scant passing about the Malacca High School in Malacca once being a breeding ground for flea by the Japanese army based on Tomosada Masuda's recorded film on Unit 9420 activities in breeding flea. While it is now known that at least three states in Malaysia were involved in Japan's biological warfare effort to cultivate flea to spread plague elsewhere, there could be other locations in Malaysia where the Japanese army and their scientists could have initiated other biological warfare initiatives which have not been explored. Lim (2020, p. 18) for instance, mentions briefly about the IMR in Kuala Lumpur being a suspected Japanese biological weapons facility under its director, Onari Kimura with malaria and dengue research being the focus. To date, no in depth study has so far been conducted about the background of any Japanese scientists who could have served at the IMR in Kuala Lumpur and the focus of their research in combating diseases such as malaria, dengue and scrub typhus. Ho (2006, p. 157) for instance, had highlighted that much remains unknown about the type of research being conducted at the IMR by the Japanese at its premises at Jalan Pahang, Kuala Lumpur during WWII. Some scholars (Khoo \& Lubis, 2005, p. 286; Kratoska, 1997, p. 190) though have highlighted that the IMR during Japanese occupation had produced typhoid, paratyphoid A and B, cholera, dysentery and gonococcal vaccines, as well as supplying emetime hydrochloride injections among local Malayan hospitals and clinics. Therefore, there exists a gap in 


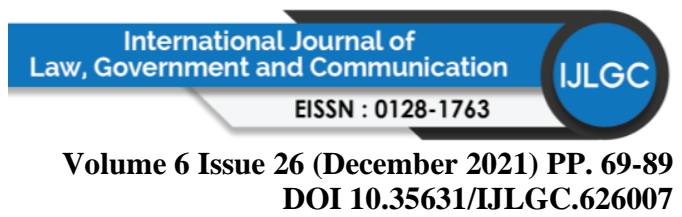

identifying who these Japanese scientists were, the focus of their research at the IMR during WWII and their final destiny after the war leaving a justification for conducting this study.

Besides the IMR in Kuala Lumpur, Japanese scholars (Iijima, 2016, p. 363; Iijima, Inoue \& Ichikawa, 2021, p. 4; Setoguchi, 2007, p. 178) have referred to one prominent scientists, Manabu Sasa who had researched on malaria in his capacity as a Japanese navy officer who was posted to Penang, Malaya for six months in 1941. Nevertheless, an existing gap currently exists if there were other Japanese scientists whose identity remain unknown and could have been posted to other locations in Malaya to conduct research either on malaria, dengue or scrub typhus. This is another grey area which this study will attempt to fill the void of identifying any Japanese scientists who could have worked on any of these diseases mentioned elsewhere in Malaya.

Furthermore, it is already known that some of the earliest Japanese universities such as Tokyo Imperial University, Kyoto Imperial University, Tohoku Imperial University, other universities and colleges in Japan had served as recruitment centres for scientists from all backgrounds be it a bacteriologist, pathologist, parasitologist, entomologist, zoologist, and many more (Felton, 2013, p. 25; Harris, 2002, p. 19; Keiichi, 2010, pp. 25-26; Lockwood, 2009, p. 105; Vanderbrook, 2013, p. 13). In the case of scientists who had served with Unit 731 and its subunits, scholars (Devolder, 2015, p. 41; Harris, 2002, p. 337; Rawlinson, 2013, p. 78) have indicated that many of these scientists safely returned to Japan without undergoing any war crime trials for their wrong doings of producing biological weapons and conducting human experimentation to hold high positions within Japanese universities such as professors, deans or any other administrative posts, to head a big pharmaceutical company, conduct research at research institutes or serve the private sector to earn fortunes. Thus, in the case of Malaya, there is a need to investigate from which universities these Japanese scientists researching on malaria, dengue and scrub typhus had originated and their destiny post WWII. This being the case, the aim of this study to identify the background and destiny of some of these Japanese scientists who conducted research on the tropical diseases mentioned and to evaluate if their actions could have led to biological warfare have been justified based on the gaps identified from this literature review.

Moreover, scholars have identified the inadequacy of international law at the end of the $19^{\text {th }}$ and early $20^{\text {th }}$ century by referring to the soft law document called the Brussels Declaration of 1874, the two Hague Conventions (II) with Respect to the Laws and Customs of War on Land (with annexed regulations) of 1899 and 1907 [thereafter the Hague Convention of 1899 and 1907], as well as the 1925 Geneva Protocol for the Prohibition of the Use in War of Asphyxiating, Poisonous or Other Gases, and of Bacteriological Methods of Warfare [hereinafter 1925 Geneva Protocol] which merely addresses the "use of poison and poisoned weapons" to imply the usage of biological weapons (Brungs, 1964; Vec, 2017). International law during this period of time had failed to address the production and stockpiling of biological weapons creating a gap (Bunn, 1970, p. 255; Levie, 1991, p. 342). Thus, any experimentation with microorganisms in the laboratory, mass producing these microorganisms for storage and eventual use, and human experimentation could be carried out by a belligerent state at that time as it was not illegal because international law omitted to address the above steps leading to the development of biological weapons. In this regard, it has to be examined if the Japanese army's experimentation with malaria and dengue mosquitoes at the IMR in Kuala Lumpur and in 


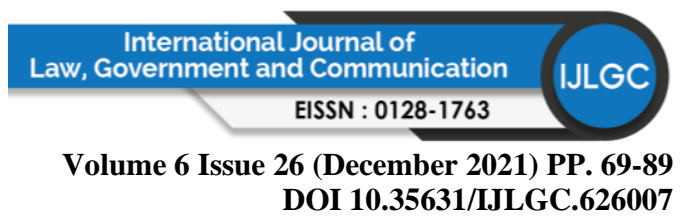

Singapore during WWII would have been punishable under international law at that time which will be elaborated in another section of this study.

\section{Methodology}

This is a qualitative study which adopts a historical research approach defined "as the process of critical inquiry into past events to produce an accurate description and interpretation of those events" (Wiersma, 1982). As such, this study utilizes primary sources of documentation. Both Japanese and English language secondary resources were also referred in this study. Japanese resources were referred as this provided a wider range of written resources about Japanese scientific researchers which has been useful for this study.

The historical documents which were used in this study consisted of the United States (US) army and navy documentation during and after WWII, a war diary and other sources which were readily obtainable online from various websites such as the National Library of Medicine in the US, the National Library of China, the Fold3-Historical Military Records website, the Trove website of the National Library of Australia, the Singapore archives, the IMR library in Setia Alam, Selangor, Malaysia, the US archives, and various online databases and open source materials from Japan. Apart from primary documentation, these online websites were very useful in retrieving past newspapers to inquire about the background of the IMR during wartime, and the background of foreign researchers from Japan who served this institute at that time. Legal documentation which were referred include the Brussels Declaration of 1874, the two Hague Conventions (II) with Respect to the Laws and Customs of War on Land (with annexed regulations) of 1899 and 1907, the 1925 Geneva Protocol for the Prohibition of the Use in War of Asphyxiating, Poisonous or Other Gases, and of Bacteriological Methods of Warfare and a Japanese case law of 2002.

Besides documents, this study also relied both on secondary resources consisting of Japanese and English publications of books, book chapters, journals, conference papers, newspapers, magazines and internet materials to obtain an overview about the structure of the IMR during the Japanese invasion of WWII, to obtain the names and backgrounds of selected Japanese scientists and their research focus on malaria, dengue and scrub typhus and thereupon their destiny and career path after leaving Malaya post WWII.

All of these documents and secondary resources were analysed through a historical analysis which is "a method of examination of evidence in coming to an understanding of the past [...] contained in documents" (Bricknell, 2011, p. 108). All the information obtained were sorted and classified according to the names of the Japanese scientists as the aim was to obtain a short biography of them. By classifying and sorting all materials according to the Japanese scientists' names, this had made it much easier for the write-up process which is descriptive and narrative being typical of historical research. 


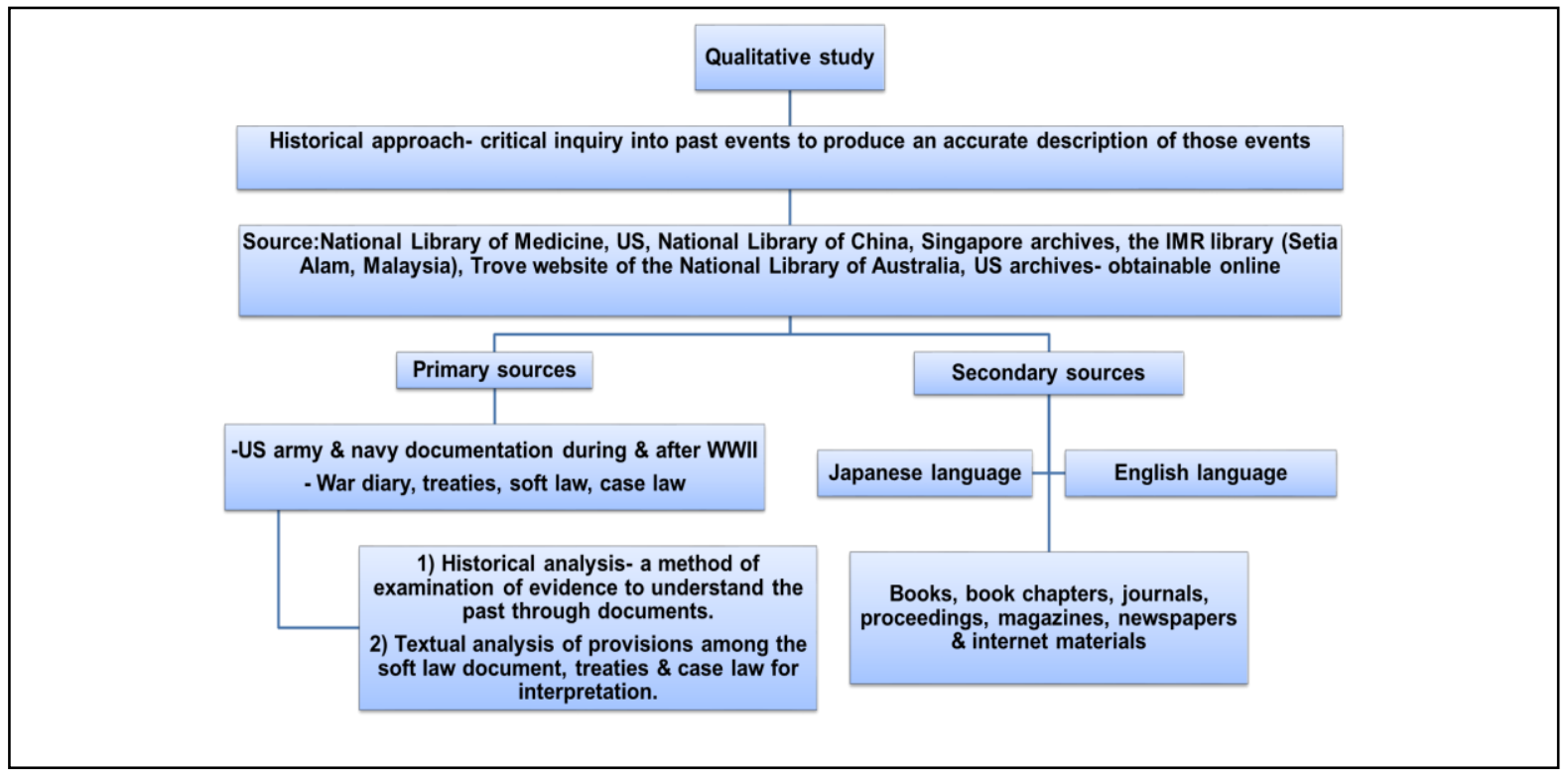

Figure 1: Summary of the Methodology Used in this Study

\section{The Results of the Study}

This section will focus on the IMR structure during the Japanese occupation and the scientists who conducted research on mosquitoes at this institute during this period. There will also be a focus on other Japanese scientists who had concentrated on diseases caused by mosquitoes and scrub typhus mites during WWII throughout Malaya. Apart from this, there will be an analysis on international law from the end of the $19^{\text {th }}$ until the early part of the $20^{\text {th }}$ century with regard to its inadequacy in addressing the preparatory process of biological weapons involving work in the laboratory which may cover the development, production and stockpiling process that does not lead to the actual usage of biological weapons on a large scale.

\section{The IMR Structure during Japanese Occupation and Japanese Scientists Research}

During WWII, the IMR in Kuala Lumpur, Malaya came under the control of two Japanese directors. They were respectively K. Sato and Onari Kimura. K. Sato became the director around November 1942 arriving from Japan ("Medical Research", 1942, p. 2). Previously in Japan, Sato had worked at various health departments but not much has been revealed during his stint in Malaya ("Medical Research", 1942, p.2). Efforts were made by the Japanese colonial master to reorganize the IMR in 1942 under the tutelage of Dr. J. Huziyosi, Director, State Medical Services in Selangor and with assistance from Dr. K. Ando, the Director of Medical Services in Singapore (Chelliah, 1942, p.3).

Under the Japanese leadership, the IMR came to be known as the Nettai Igaku Kenkyusho (Tropical Medicine Research Institute) and was divided into the following divisions. There was a malaria division being formed to undertake a microscopical examination of thick and thin blood films to screen for malaria parasites. Besides this, this division was tasked with identifying mosquitoes and larvae for the Japanese Health Department in screening for malaria.

Apart from this, the bacteriological division was also formed in the IMR. This division would look into the culture of blood and urine in diagnosing for typhoid, dysentery, and other 


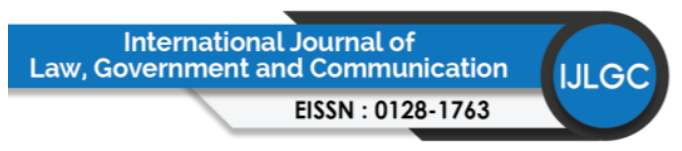

Volume 6 Issue 26 (December 2021) PP. 69-89 DOI 10.35631/IJLGC.626007 infectious diseases. The said division would also undertake a bacteriological examination of the water supply, milk samples and other foods (Chelliah, 1942, p.3) Other functions of this division include a biochemical and microscopical examination of blood and urines and a chemical analysis of water and milk supplies (Chelliah, 1942, p.3).

In 1943, there was a change in leadership at the IMR whereby Onari Kimura became the head of the Nettai Igaku Kenkyusho. During his tenure, the IMR produced vaccines for cholera, typhoid, smallpox, diphtheria, and tetanus ("Anti-toxins to", 1944, p.3). During Kimura's time as director too, the IMR also produced gonococcal vaccines and emetime hydrocholoride infections to local hospitals (Khoo \& Lubis, 2005, p.286). When the war ended in 1945, Kimura left for Japan, but the local staff remained behind. However, the IMR was being stripped off most of its equipment with laboratories having to be reequipped ("Medical Research", 1949). Moreover, other essential bacteria and viruses had to be flown from overseas to the IMR in Kuala Lumpur as the institute was more less stripped bare by the Japanese ("Medical Research", 1949).

\section{Onari Kimura}

Of interest is the background of Onari Kimura who was a professor at Tohoku Imperial University in Sendai, Japan (Nichigai Associates, 2004). Kimura was born on 10 January 1883 in Kiyosu, Yamaguchi Prefecture and passed away on 29 June 1954 (Nichigai Associates, 2004). Kimura graduated in 1910 from Tokyo Imperial University School of Medicine majoring in psychiatry but later pursed his studies in pathology at Germany and France in 1884 (Nichigai Associates, 2004). By 1918, Kimura became a professor at Tohoku Imperial University and in 1929 became the president of the Japanese Society of Pathology (Nichigai Associates, 2004). Kimura once worked at the Department of Psychiatry at the Mukden Medical School in China. Peripheral and central nerves, tuberculosis and syphilis were some areas of specialization of Kimura. Besides being the director of the Nettai Igaku Kenkyusho, Kimura was also the director of the Syonan Ika Daigaku (Medical College) which had moved from Singapore to Malacca in 1944 ("Ika Daigaku being", 1944, p. 11). When the Japanese captured Malaya, they had in mind to bring together the IMR which they referred as the Southeast Asia Medical Research Institute specializing in malaria together with other academic institutes to be part of the envisioned University of Greater East Asia or Syonan University with its base in Singapore (Singapore was then known by the Japanese as Syonan) (Shinsei, 1942, p. 2). This explains the reason Kimura was both the director for the Nettai Igaku Kenkyusho in Kuala Lumpur and the Syonan Ika Daigaku in Malacca, as the Japanese decided to integrate the IMR as part of Syonan University.

In a chapter written by Ichinohe (2016, p. 52) entitled "The Fifteen Years War and Tohoku Imperial University" which is part of the book on Unit 731, he mentions about Onari Kimura being the director of Nettai Igaku Kenkyusho in Malaya. Nevertheless, Ichinohe does not directly mention that Onari Kimura was part of Unit 731 but academics from Tohoku Imperial University during WWII whether willingly or unwillingly were recruited by the IJA to contribute to research for the furtherance of warfare. Based on Ichinohe's writings, indeed there is a suspicion that Onari Kimura could have been part of the Unit 731 network and he was once stationed at the IMR in Kuala Lumpur, Malaya during WWII.

It remains to be seen someday whether the truth will ever surface if the IMR or Nettai Igaku Kenkyusho during Japanese imperialism in Malaya was ever used for any sinister activities as 


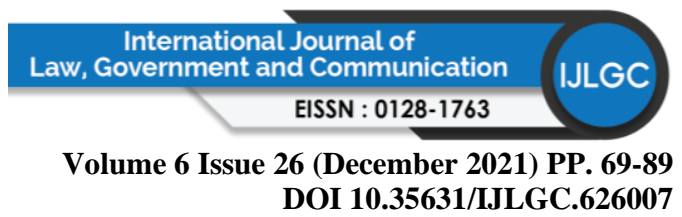

more evidence will have to come to light. It is only sufficient to note that one of the IMR's Japanese director might have been part of Unit 731 as implied by Ichinohe's writings and an individual of this stature is someone to be wary about. Notably after WWII, Kimura safely went back to Japan to continue his tenure as a professor at Tohoku Imperial University until he died.

\section{Masahiro Ogaki}

Besides Onari Kimura, two other Japanese researchers from the period of 1941-1945 were attached to the IMR. One of them was Masahiro Ogaki, attached to the IMR in 1945 as evident in his writings entitled "Bird malaria parasites found in Malay Peninsula" which was published in 1949 (Ogaki, 1949). In this article by Ogaki, it is evident there had been interaction with the local staff of the IMR, in this case being J.A. Chelliah who assisted Ogaki with his research. At this point of time, Ogaki served Kyoto University and was a young researcher. Ogaki survived the war and went back to Japan to have an illustrious academic career. At this juncture, Ogaki moved to serve the Department of Biology, University of Osaka Prefecture, Sakai, Japan. Ogaki's concentration on malaria confirms that during Japanese occupation, the IMR had a malaria division. Ogaki himself was a graduate from Hiroshima University of Literature and Science and for a time served at the Kyoto Prefectural Daiichi High School as a high school teacher and later junior high school teacher (Osaka Prefecture University, 1983). He then went on to be employed at the National Institute of Genetics, Ministry of Education, Culture, Sports, Science and Technology in Japan (Osaka Prefecture University, 1983). Thereupon, Ogaki became an associate professor at the Faculty of Education, Naniwa University which would later be known as Osaka Prefecture University (Osaka Prefecture University, 1983, p.7). Ogaki acquired his Doctor of Science from Osaka University and in his early 40s was promoted to a professor at the Faculty of Liberal Arts, Osaka Prefecture University (Osaka Prefecture University, 1983, p. 7). With seniority, Ogaki became a councillor at Osaka Prefecture University and retired at 58 years old (Osaka Prefecture University, 1983, p.7). He was later appointed as Professor Emeritus and passed away in 2012 ("Fōramu", 1998, p. 205). Ogaki himself was born in 1920 and was even a consultant for the World Health Organization (WHO) ("Fōramu", 1998, p. 205). Evidence has not come to surface so far if Ogaki was a member of the Japanese machinery for biological and chemical weapons, Unit 731 nor Unit 9420 in Singapore. In a journal paper written by another Japanese academician know as Masatoshi Iwata, he mentions that Ogaki had introduced him to military medicine (Iwata, 1952, p. 249). Iwata himself was working at the IMR together with Ogaki in the area of malaria and the former mentioned he had worked with monkeys which presumably could imply monkey malaria or the word monkey could refer to experimentation with humans (Iwata, 1952, p. 249). In disguising their experimentation on humans, the Japanese scientists were known to refer to them as monkeys when writing in journal papers (Harris, 2003, p. 481).

\section{Masatoshi Iwata}

As to the background of Masatoshi Iwata, he was born in 1897 at Arashima-cho, Shimane Prefecture (now Yasugi City) (Yamauchi, 2016, p.70). Iwata joined the Department of Animal Science, the Faculty of Science, Kyoto Imperial University in 1923 with his research focusing on caddisfly larvae (Yamauchi, 2016, p. 70). Upon graduation in 1927, Iwata moved to the Otsu Rinko Experiment Station attached to Kyoto Imperial University (Yamauchi, 2016, p. 70). Subsequently in 1930, Iwata transferred to Osaka Medical University (presently Osaka University School of Medicine), studying under Sadao Yoshida to focus on parasite research (Yamauchi, 2016, p. 70). During WWII, the IJN commissioned Iwata to conduct research on 


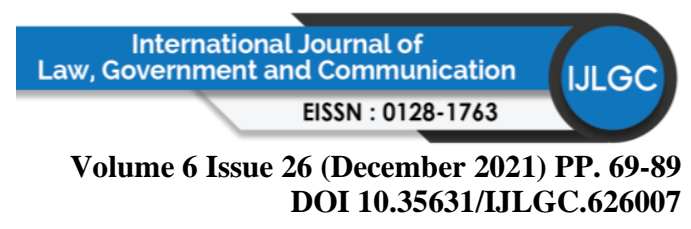

parasites at Papua New Guinea and Malaya (Yamauchi, 2016, p. 70). In a captured war diary from Guam Island, it has been indicated that Iwata whose pen name was also Seishun Iwata had published a number of articles and pamphlets on mosquitoes, namely on malaria and dengue and was also stationed at Kuala Lumpur (United States Medical Research Unit, 1946, p. 171). Moreover, the information on Iwata's whereabouts during WWII, in the said dairy also made it into a column entitled "The War and Biological Sciences in Japan" which was published in 1946 in the journal Science but it was never mentioned that the source was from the said war diary (Gressit, 1946, pp. 756-757). Iwata himself admitted to working at the Nettai Igaku Kenkyusho in Kuala Lumpur during WWII conducting his research on malaria as indicated in his article "The Tendency of Research on Parasitology in Japan during the Pacific War" (Iwata, 1952). In 1952, Iwata was a professor at Nara University of Education who taught biology and thereupon retired in 1963 (Yamauchi, 2016, p. 70). In April 1963, Iwata subsequently lectured at Shimane University School of Medicine and later died at 100 years old in 1997 (Yamauchi, 2016, p. 70). At this point of writing and to the best of this author's knowledge, there is no written evidence indicating Iwata was part of Unit 731 but a captured war diary by the US was suspicious of his research.

\section{Kiyoshi Hayakawa}

Apart from this, Iwata has also indicated that Kiyoshi Hayakawa had focused on tropical diseases with a focus on scrub typhus while at Singapore which was also mentioned in the IMR's 50 ${ }^{\text {th }}$ jubilee document (Iwata, 1952, p. 251; Wu, 1951). In the Hill and Victor (1947) report which focused on biological weapons, it is evident from an interview with Kiyoshi Hayakawa of 17 November 1947 that he had served in Singapore starting from 1942 and his study had focused on tsutsugamushi differentiating it from scrub typhus fever. Kiyoshi Hayakawa was the Director of the Japanese Army Institute of Preventive Medicine (Nampogun Boekukusai Bu) at the former King Edward VII College in Singapore (Kathirithamby-Wells, 2005, p. 257). Under the leadership of Hayakawa, scrub typhus research was conducted in Java, Sumatra, and Malaya (Kathirithamby-Wells, 2005, p. 257). In the post-war period, the Hayakawa Medical Company was formed employing former Unit 731 members (Harris, 2002, p. 178). Recent revelations of Unit 9420 members which was Japan's main research base for biological weapons in Southeast Asia has indicated that Hayakawa was one of its members (Nishiyama, 2019, p. 49). 


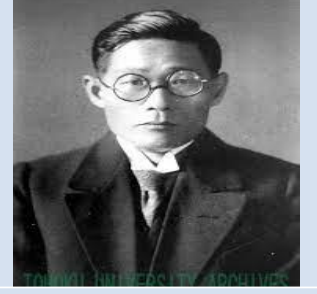

ONARI KIMURA (18831954)

Was a professor at Tohoku Imperial University and the second Japanese Director of the Institute of Medical Research

(IMR) in Kuala Lumpur and the Syonan Ika Daigaku (Medical College) in Malacca

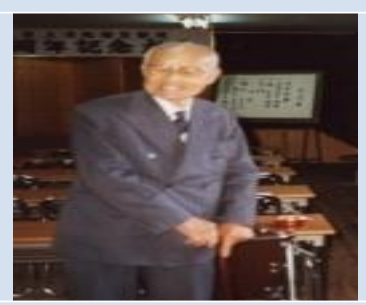

MASATOSHI IWATA (@SEISHUN IWATA, 1897-1997)

Was a professor and commissioned by the Imperial Japanese Navy (IJN) to conduct research on malaria dan dengue at Papua New Guinea and Malaya, end of World War II was found in Kuala Lumpur

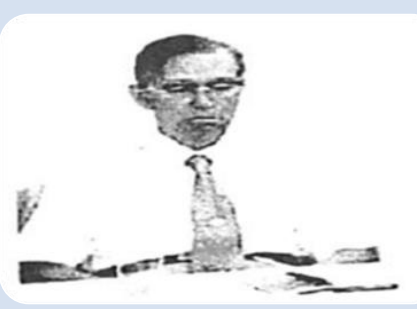

MASAHIRO OGAKI (1920-2012)

Was attached to the IMR in 1945 and in 1949 published an article entitled "Bird Malaria Parasites Found in Malay Peninsula", worked together with Masatoshi Iwata at the IMR, Kuala Lumpur

Figure 2: Japanese Scientists Who Served at the Institute of Medical Research in Kuala Lumpur during World War II

Source and photos: Center for Ecological Research, Kyoto University (1984), Fōramu (1998), Gressit (1946), Ichinohe (2016), Iwata (1952), Ogaki (1949), Tohoku University Archives (2007), United States Naval Medical Research Unit No. 2 (1946), Yamauchi (2017).

\section{Research on Malaria and Dengue Elsewhere in Malaya}

Besides the research on malaria conducted at the Nettai Igaku Kenkyusho in Kuala Lumpur, research on mosquitoes have been conducted elsewhere in Malaya by researchers mentioned below:.

\section{Manabu Sasa}

In Penang, for the first half of 1941 a researcher called Manabu Sasa who graduated from the Tokyo Imperial University School of Medicine in 1940 was a Japanese navy medical officer (Setoguchi, 2007, p. 178). While in Penang, Sasa conducted surgery for the navy in the morning while his afternoons were spent trying to learn about diseases in the tropics including malaria. Sasa was taught to distinguish which species of mosquitoes which caused malaria by the local Malayan doctors (Setoguchi, 2006). Having prior knowledge about the British literature on malaria, Sasa knew that substantial research had been done in this area. However, in Japan, there was little focus being given towards entomological research encompassing the taxonomy and ecology of insect vectors. The presence of Japanese troops in Malaya and other parts of Southeast Asia as well as the Pacific islands which had lots of anopheles mosquitoes causing malaria to take a toll on the Japanese army meant that extensive research by Japanese scientists was needed to look for a cure. Existing British papers concerning research on malaria was translated by Sasa to Japanese whereupon this valuable knowledge was transmitted to the Japanese Navy Medical School in Tsukiji, Tokyo (Setoguchi, 2006). The Japanese on their part were in awe with the British and Allied advancement knowledge in identifying the mosquito species causing malaria which indicated that the enemy were at the forefront of research in this area as compared to the Japanese (Setoguchi, 2006). Upon his return to Tokyo, Sasa became a part of the Institute of Infectious Diseases (also known as Denken) at the University of Tokyo 


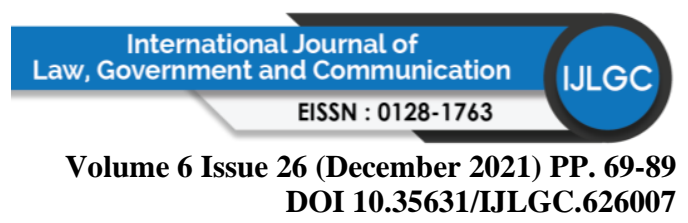

and would continue his research on mosquitoes and medical entomology overall to reach greater heights in his career to become a professor. Sasa passed away in 2006 (Setoguchi, 2007, p. 178).

Noteworthy, the US Technical Mission to Japan after the war ended had prepared a report on the Pharmacology and Malariology in Japan - Civilian and Navel dated 7 January 1946 (US Naval Technical Mission to Japan, 1946). The US on their part conducted this investigative initiative to ascertain the form of malaria research being conducted by the Japanese Naval Medical College whether there was any suspicious research to raise the alarm. As it turns out to be, the report on Pharmacology and Malariology in Japan (US Naval Technical Mission to Japan, 1946, p. 38) had highlighted Sasa's research "on the prevention on malaria" and his research on the "biological examination of medicine for cure and prevention of malaria" which was conducted together with I. Miyao and H. Hosoya. At that point of time, the US sent representatives to a substantial number of universities in Japan which were involved in wartime research to interview many researches just in case there was any research to garner suspicion leading to the development of biological weapons and human experimentation. After all, in Rabaul, Papua New Guinea, a Captain Einosake Hirano of the Rabaul Water Purification Unit, an affiliated medical unit of Unit 731 based in Manchuria, China was found guilty of injecting tainted malaria blood from infected Japanese troops among Australia, New Zealand and American prisoners of war (Felton, 2012, p. 81). In Singapore too, a captured Indian soldier indicated that the Japanese army had experimented malaria on the prisoners of war on this island (Supreme Commander for the Allied Powers, 1947, p. 10). Therefore, it is only befitting for the US to further inquire if any other universities and institutes in Japan after WWII had conducted any research on malaria which could raise any misgivings.

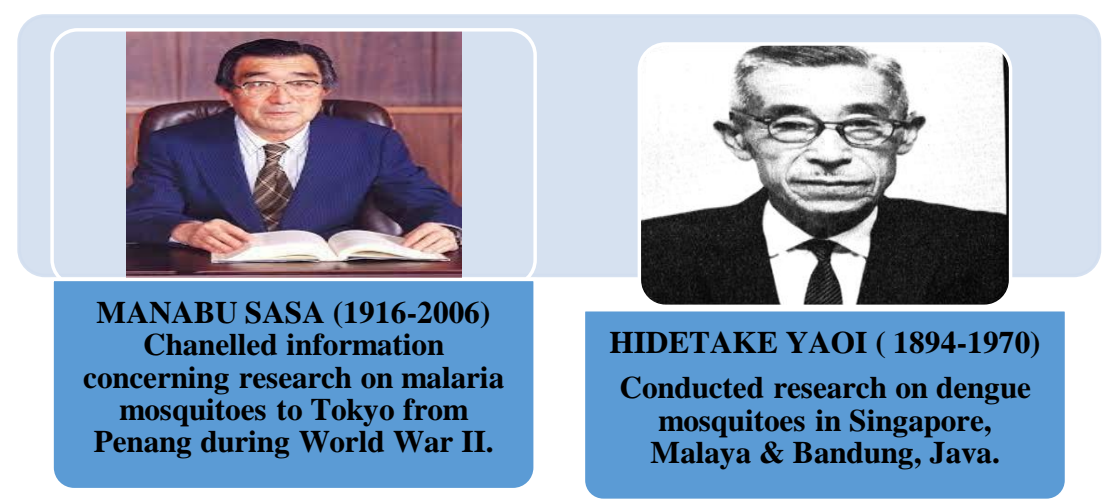

Figure 3: Mosquito Research Conducted by Other Japanese Scientists Elsewhere in Malaya and Southeast Asia

Source and photos: Arakawa (1970), Iijima (2016), Manabu Sasa 100th anniversary project (2006).

\section{Hidetake Yaoi}

Besides malaria, the Japanese also conducted research in looking for a cure against dengue fever. One such Japanese researcher was Hidetake Yaoi who graduated from Tokyo Imperial University School of Medicine in 1920, became a technician at the Institute of Medical Science attached to the University of Tokyo in 1923 and obtained his Doctor of Medicine in 1926 (Arakawa, 1970). In September 1943, during WWII, Yaoi was temporarily commissioned by the Japanese War Ministry to conduct research on dengue fever in Malaya, Singapore, and Bandung (Arakawa, 1970, p. 578). Towards the end of October 1943, it was reported that Yaoi was visiting Nampo (the Southern region) to complete his research work on dengue as he had 


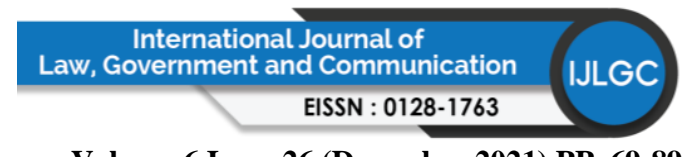

Volume 6 Issue 26 (December 2021) PP. 69-89 DOI 10.35631/IJLGC.626007

previously devised serum therapy against dengue fever ("Nippon doctor", 1943, p.1). While in Singapore and Bandung, Yaoi conducted human prophylactic experiments and created fly antigens using monkeys (Arakawa, 1970, p. 578).

Yaoi features as an assistant to Saburo Kajima who was heading the manufacturing Department of the Institute for Infectious Diseases at Tokyo Imperial University as indicated in a document called "References from the Committee for the Technical and Scientific Survey of Japanese Activities in Medical Sciences" (US Naval Technical Mission to Japan, 1945) where both names are identified right after WWII. The said report was prepared by the Committee for the Technical and Scientific Investigation of Japanese Activities in Medical Sciences which was established in Manila in August 1945 to "examine and evaluate Japanese installations and personalities associated with medical sciences [...] and to correlate the activities of the medical section of the Enemy Equipment Intelligence Units" (Anderson, Hoff \& Hoff, 1971, p. 229). Committee members visited overall 32 various Japanese universities and medical institutions with 200 individuals being interviewed to gain an insight about the kind of wartime research being conducted which could lead to the suspicion of producing biological weapons (Anderson, Hoff \& Hoff, 1971, p. 229). Yaoi's Manufacturing Department itself at Tokyo Imperial University was responsible for producing serums, vaccines, toroid, and other biologic products while his head, Saburo Kajima much later was determined to be a member of Unit 731, the Japanese secret unit for producing biological weapons in China (Shibata, 1996, p. 119; US Naval Technical Mission to Japan, 1945, p. 9).

Yaoi's research work on serum therapy for dengue fever was enough to alert the Allied powers during WWII about the application of dengue for biological warfare. This research work was done together with another Japanese researcher named Seiji Arakawa. In an article entitled "The Fighting Scientists" written by Tsuji Sato in January 1944 in the Fuji magazine, the serum therapy concocted by Yaoi and Seiji Arakawa was hailed as a Japanese achievement to defeat the enemy (Allied Translator and Interpreter Section (ATIS), 1944). The serum therapy created was said to assist in bringing down high fever, pain and loss of appetite and could reduce the number of Japanese troops inflicted with dengue fever at the Solomon Islands and Papua New Guinea (ATIS, 1944). Moreover, the Japanese were also concerned if dengue could be widespread within Japan when its army and navy returned to their mainland. In 1942 for instance, a navy ship returning from the Malay Peninsular brought the dengue fever to Nagasaki (LaCasse, 1949, p. 10). A puddle on the navy ship infested with the dengue mosquito larvae had caused dengue fever to eventually spread to other areas in Japan such as Kyushu and around the Kobe, Osaka, and Kyoto areas in the south of Honshu (LaCasse, 1949, p. 10). Therefore, Japanese parasitologist, entomologist and other scientists were being deployed abroad to conduct research for preventive measures and to look for a cure in combating diseases brought by mosquitoes as it was envisaged that more returning Japanese troops from the Pacific War would be afflicted with insect bearing diseases. The Allies during the war were concerned if dengue could be a "terrifying weapon in that the Japanese could inflict with dengue the many thousands of enemy troops which infest the Solomons and New Guinea" as this would have been a case of using insects and the disease they bring for biological warfare (ATIS, 1944). As Yaoi was commissioned to conduct research on dengue and possibly taking samples of these mosquitoes in Malaya and Singapore, this is a scientist to be wary about given the controversy of his research as highlighted by the Allies. 


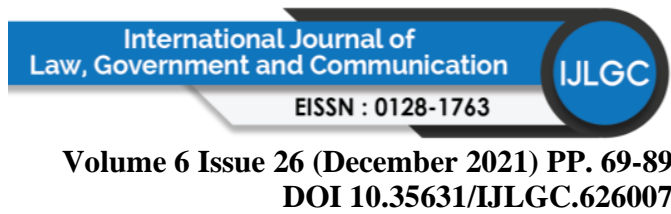

The International Law Gap to Address Preparations of Biological Weapons by the Japanese Army

\section{Mid-19th Century - 1900}

The Lieber Code that was signed by President Abraham Lincoln on 24 April, 1863 at the time of the American Civil War had set the precedent in prohibiting the use of poison during warfare ("The war of the rebellion", 1899). Article 16 of the Lieber Code mentions that "it does not admit to the use of poison in any way", which refers to the taboo of using poison ("The war of the rebellion", 1899). Article 70 of the Lieber Code asserts that "[t]he use of poison in any manner, be it to poison wells, or food, or arms is wholly excluded from modern warfare. He that uses it puts himself beyond the pale of the law and the usage of war" ("The war of the rebellion", 1899). Furthermore, in Article 13 (a) of the 1874 Brussels Declaration concerning the Laws and Customs of War, there is reference to the use of poison or poisoned weapons that implies the use of biological weapons (Brussels Committee, 1874). The negotiating history of the Brussels Declaration indicates of a phrased proposed which is "the use of poisoned weapons of the spreading, in any means whatsoever of disease on enemy territory" (Brungs, 1964). Much later, the word "spreading" was omitted and simplified as "the use of poison and poisoned weapons" as reflected in the final Brussels Declaration of 1874 (Brungs, 1964). Indeed, the reference to disease in the context of the phrase "the use of poison and poisoned weapons" garnered a few proposals in the debate of the Brussels Declaration. There was a proposal that "the use of poison and poisoned weapons" should be interpreted to forbid "the employment of all substances which are of nature to spread in the occupied country any contagion whatsoever" (Brungs, 1964, p. 48). There was also a view that disease should be left within the ambit of the Sanitary Convention as it was irrelevant to the Brussels Declaration (Brungs, 1964). In the end, the governments which were involved in the negotiations of the Brussels Declaration did not ratify this document. However, the Brussels Declaration is significant as it is a pioneer document with reference to diseases in the context of biological weapons.

Indeed, Article 23 (a) of the Convention (II) with Respect to the Laws and Customs of War on Land (1899) which prohibits the use of poison or poisoned arms traces its roots directly to the Brussels Declaration of 1874 (Hague Convention, 1899). The minutes of the two Hague Conferences (1899 and 1907) indicated that the negotiators fully adopted the phrase "poison and poisoned weapons" without further changes to refer to the spread of contagious diseases as indicated in the previous Brussels Declaration (SIPRI, 1973, p. 96).

\section{The Period 1900 - 1940s}

Similarly, Article 23 (a) of the Hague Convention IV (1907) which forbids the use of poison or poisoned weapons takes after the wording from the Brussels Declaration of 1874. The reference to the Hague Conventions of 1899 and 1907, and Brussels Declaration was reflected in a court case relating to compensation claims by Chinese citizens who were victims of Japan's biological weapon's testing during World War II in Manchuria. The judge Koji Iwate asserted "there can be no argument with the statement that even at the time of the aforementioned Brussels Conference [of 1874,] germ warfare against countries involved in the fighting was to be prohibited" (Tokyo District Court, 2002, p. 5). This implies that the prohibition of biological weapons has been accepted as a norm for a long period of time to become customary international law. With regard to the Chinese plaintiffs reference to Article 23 of the Hague Convention for War on Land that prohibits poison and poisoned weapons, it was concluded 


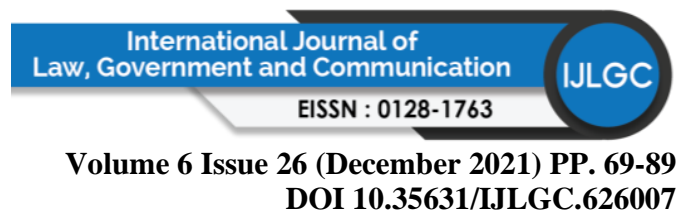

that "Article 23 Section [II] - prohibiting the employment of 'poison or poisoned weapons'applies to biological weapons" as the Brussels Conference of 1874 had already affirmed this matter (Tokyo District Court, 2002, p. 5). Moreover, the judgment indicated "that the Hague Convention for War on Land had been established at the latest by 1911 as international customary law" (Tokyo District Court, 2002, p. 5). Since Japan had signed and ratified both the Hague Conventions of 1899 and 1907, it had the legal obligation to abide by its provisions.

Similarly, the Geneva Protocol (1925) which was signed but never ratified by Japan until 1970 also banned the use of asphyxiating, poisonous or other gases, which was extended to the prohibition and use of bacteriological methods of warfare. In the same Tokyo District Court's judgment of 2002, it was reaffirmed that since "the [Geneva] protocol went into effect in 1928, by that time at the very latest the legal certainty regarding the protocol had been established among most nations of the world and that therefore that international customary law had been established based on the articles of the protocol" (Tokyo District Court, 2002, p. 5). Although the 1899 and 1907 Hague Conventions and the 1925 Geneva Protocol were written treaties that codified the ban of using poison, prior to this it has already been established through customary international law that such practice has long been barred.

While it has been widely accepted there exists in customary international law the prohibition to use biological weapons, throughout the end of the 19th century until 1972 there was a lacuna in the failure to have a binding agreement which would address the development, production and stockpiling of biological weapons. Japan conducted many experiments in laboratories and resorted to human experimentation in its quest to successfully develop biological weapons in China and its occupied territories in Southeast Asia including then Malaya. In this regard, this involved the production and development of biological weapons in large quantities to be stored for eventual usage against the Allies which involved stockpiling. Thus, it cannot be said that Japan had used biological weapons on a large scale on its enemies but human experimentation was definitely involved. This makes it a weak case to apply the Brussels Declaration of 1874, the Hague Conventions of 1899 and 1907 nor the 1925 Geneva Protocol banning the use of poison or poisoned weapons against Japan unless substantive evidence shows actual widespread usage of biological weapons against Japanese enemies.

Indeed, the gap in international law from the end of the 19th century in its failure to address the experimental phase to develop biological weapons which does not lead to its actual usage required that domestic law be applied to punish the Japanese wrong doers as reflected in the Khabarovsk trial of 1949 (SIPRI, 1973, p. 141). The Japanese army involved in developing biological weapons were charged with having "prepared and used" bacteriological weapons (SIPRI, 1973, p. 141). It is for this reason that the Khabarovsk trial referred to the domestic law of the Soviet Union as reference rather than general international law per se because of the existing gap already mentioned.

Noteworthy, states which were parties to the League of Nations from the period of 1932-1934 had organised a Disarmament Conference with the intention to negotiate a Disarmament Convention based on a British draft text which came to naught (SIPRI, 1971, p. 37). Excerpts from the British draft text of the Convention do refer to the prohibition of preparing biological weapons as referred in Article 51 below: 


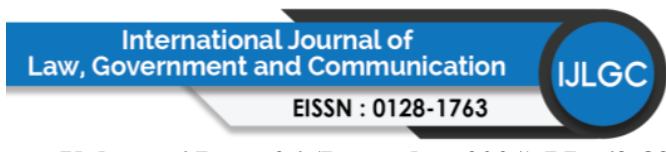

Volume 6 Issue 26 (December 2021) PP. 69-89 DOI 10.35631/IJLGC.626007 All preparations for chemical, incendiary or bacterial warfare shall be prohibited in time of peace as in times of war (SIPRI, 1971, p. 168).

Moreover, the British draft text Disarmament Convention would have provided an avenue for any alleged complaints of states attempting to develop biological weapons as this was part of the preparation process through Article 55 which reads as:

The Permanent Disarmament Commission shall examine the complaints put forward by any Party which may allege that the prohibition to prepare for chemical, incendiary or bacterial warfare has been violated (SIPRI, 1971, p. 169).

In this regard, a Permanent Disarmament Commission would have the responsibility to investigate a complaint that a particular state was in the process of developing and producing biological weapons.

Unfortunately, the negotiations for a Disarmament Convention came to a halt around the period of 1934-35. Some factors which led to the breakdown in negotiations include the German withdrawal when Adolph Hitler took over Germany, Germany's rearmament, the imbalance and unfairness of requiring Germany to disarm after World War I but excluding other major parties involved in this war, and there was a lukewarm response among other states to truly disarm. With the breakdown of negotiations, this failed to produce the first disarmament agreement which would have prohibited the preparation of biological weapons whether in laboratories, human experimentation and its mass production of stockpiling. In the words of Levie (1991, p. 342), the "League of Nations Disarmament Conference discussed the matter and attempted, albeit unsuccessfully, to draft a treaty which would have prohibited the production and stockpiling of both chemical and biological weapons". In the end, international law merely succeeded prohibiting the use of biological weapons with the existence of the 1899 and 1907 Hague Conventions, and 1925 Geneva Protocol mentioned earlier. If the Disarmament Convention had succeeded in coming into being, this may be a deterrent to Germany and Japan before and during WWII to embark on developing and producing biological weapons but this was not to be the case. It was not until 1972 when the Convention on the Prohibition of the Development, Production and Stockpiling of Bacteriological (Biological) and Toxin Weapons came into being that the preparatory process of developing biological weapons was being monitored.

Based on the analysis of international law which merely prohibited the use of biological weapons from the end of the 19th century up till the mid-1940s but not its development, production and stockpiling, it seems that the Japanese experimentation with malaria mosquitoes at the IMR laboratory in Kuala Lumpur and dengue mosquitoes in Singapore if ever intended for entomological warfare cannot be classified as an offense as the "use" of poison since there was no evidence of large scale usage. This assertion is made based on the Brussels Declaration of 1874, the two Hague Convention of 1899 and 1907 as well as the 1925 Geneva Protocol which merely prohibited the use of poison and poisoned weapons. Given the gap in international law at that time, the Japanese army would have been free from any accusations of wrong doing for experimenting with microorganisms and biological agents as this was not tantamount to usage. 


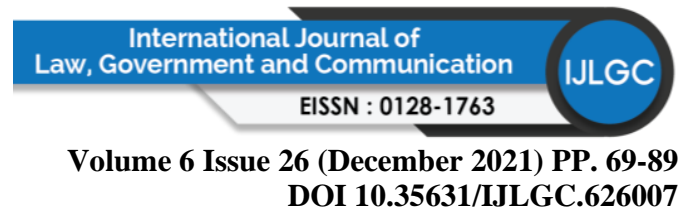

\section{Conclusion}

In conclusion, this study managed to identify the background and destiny of few Japanese scientists conducting research on malaria, dengue, and scrub typhus in Malaya while the dengue research of one of them could have been meant for biological warfare as suspected by the Allies. Much later now in the 21st century, evidence has surfaced to show that some of these scientists have been associated with Unit 9420 and Unit 731, the Japanese covert biological and chemical warfare programmes. For the scientists who were associated with biological warfare or conducted human experimentation, they were never punished for their misdeeds but safely went back to Japan to resume their normal life and hiding their dark secret with hopes of no revelation. It was most unfortunate too that the Japanese army's experimentation with malaria and dengue mosquitoes would not have been illegal in international law during WWII because existing soft law and treaties at the end of the 19th and early 20th century merely addressed the usage of poisoned weapons to encompass biological weapons but not its preparation stage to include experimental research. As for the research at the IMR, more studies needs to be done to reveal other Japanese scientists who had worked on vaccines for typhoid, paratyphoid, cholera and other diseases of concern during WWII as there exists a gap in this area for future research. Moreover, it is integral to reveal more locations in other Malaysian states which could have contributed in some way to Japan's biological warfare effort but still remains unknown besides Johor, Negeri Sembilan, Malacca and the town of Kuala Lumpur where the IMR is located. For the sake of enriching Malaysia's missing history concerning biological warfare during Japanese occupation, scholars are encouraged to overcome these hurdles of obtaining past documentation available mostly abroad to produce scholarly work for the record and knowledge of future generations. This way, Malaysians and other scholars worldwide will get a better picture about Japanese biological warfare efforts how little it may be in then Malaya as this is a mystery waiting to be unravelled.

\section{References}

Allied Translator and Interpreter Section (ATIS), South West Pacific Area. (1944). Research report on the Japanese army and germ warfare (ATIS, SWPA Report No. 84). Allied Translator and Interpreter Section. http://202.106.125.152/catalog/pc/djreader.html?read=VjFaU1MxSXIVbGRpTTNCc VVucHNZVlp1Y0ZOTmJGSldWVzVLYkZKVVJscFZWekV3V1ZkR1ZXSkVUbG hoTWxKaFdrZDRUbVZIVGtkaVJsSm9ZVEJaTVZaR1ZsTlJhelZXVFZoQ1dGWjZ Sa3haVjNoWFpFWINWMVJzY0d4V1ZFWlZWakZvYjFNeVJYcGhSbHBXWWta R00xVk

Anderson, R.S., Hoff, E.C., \& Hoff, P. M. (Eds.). (1971). Preventive medicine in World War II, vol. ix; Special fields. Office of the Surgeon General, Department of the Army, United States.

Anti-toxins to be mass produced in Selangor. (1944, December 22). Syonan Shimbun, 3. https://eresources.nlb.gov.sg/newspapers/Digitised/Article/syonantimes194412221.2 .22

Arakawa, S. (1970). Ya o ihi de take sensei [Dr. Hidetake Yaoi]. Nihon Saikingaku Zasshi, 25(11), 575-579.

Bricknell, D. (2011). Historical analysis. The SAGE dictionary of qualitative management research (pp. 108-109). Chicago: Sage. Retrieved from https://dx.doi.org/10.4135/9780857020109.n50

Brungs, B. J. (1964). The status of biological warfare in international law. Military Law Review, 


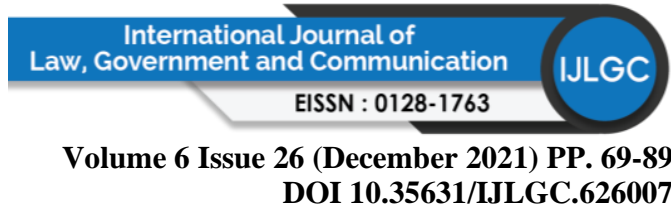

https://www.loc.gov/rr/frd/Military_Law/Military_Law_Review/pdffiles/276077 1.p df

Brussels Committee [1874]. Project of an international declaration concerning the laws and customs of war. Brussels, 27 August 1874. Retrieved December 11, 2015, from https://www.icrc.org/applic/ihl/ihl.nsf/xsp/.ibmmodres/domino/Open

Attachment/applic/ihl/ihl.nsf/42F78058BABF9C51C12563CD002D665

/FULLTEXT/IHL-7-EN.pdf.

Bunn, G. (1970). Gas and germ warfare: International legal history and present status. In M. S. Meselson (Ed.), Symposium on chemical and biological warfare (pp. 253-260). National Academy of Sciences, United States. https://www.pnas.org/content/pnas/65/1/253.full.pdf

Center for Ecological Research, Kyoto University 京都大学生態学研究センター。 (1984, October 6). Shikiten kaijō nite Iwata Masatoshi, imanishi kinji, Miyaji Denzaburō, Kawai teiji [At the ceremony venue Masatoshi Iwata, Kinji Imanishi, Denzaburo Miyaji, Sadaji Kawai]. Retrieved from: https://www.ecology.kyotou.ac.jp/HP_ArchivePhoto/70syunen/70syunen\%20(13).jpg

Chelliah, J. A. (1942, August 13). Schoolchildren's work impresses garrison chief: Exhibits for Tokyo. Syonan Shimbun, 3. https://eresources.nlb.gov.sg/newspapers/Digitised /Article/syonantimes 19420813-1.2.36?ST=1\&AT=search\&k=Schoolchildren\%27s work impresses garrison chief: Exhibits for Tokyo\&QT=schoolchildren,work,impresses, garrison,chief,exhibits,for,tokyo\&oref=article

Convention (II) with Respect to the Laws and Customs of War on Land and Its Annex: Regulations concerning the Laws and Customs of War on Land. (1899), Jul. 29 1899, 32 Stat. 1803, TS No. 403.

Convention (IV) Respecting the Laws and Customs of War on Land and Its Annex: Regulations concerning the Laws and Customs of War on Land. The Hague, Oct. 18, 1907, 36 Stat. 2277, TS No. 539.

Devolder, K. (2015). U.S. complicity and Japan's wartime medical atrocities: Time for a response. American Journal of Bioethics, 15(6), 40-49. https://www.researchgate.net/publication/277559760_US_Complicity_and_Japan's_

Wartime_Medical_Atrocities_Time_for_a_Response

Felton, M. (2012). The devil's doctors: Japanese human experiments on Allied prisoners of war. Pen \& Sword Books Ltd.

Fong, P. (2000). Inter arma enim silent leges: The Impunity of Japan's secret biological warfare unit. New Eng. Int'l \& Comp. L. Ann., 6, 1-15.

Fōramu : Chi Megumi no risaikuru o mezashite [Forum: Aiming to recycle wisdom]. (1998). Kankyō to kenkō, 11(5), 205-244. http://www.taishitsu.or.jp/E-H/E-H-11/11-5.pdf

Galvin, R. J. (2003). The case for a Japanese truth commission covering World War II era Japanese war crimes. Tulane Journal of International and Comparative Law, 11, 59115.

Gold, H. (1997). Unit 731 testimony. Tuttle Publishing.

Gressit, L. (1946). The war and biological sciences in Japan. Science, 103(2687), 755-758.

Harris, S. H. (2002). Factories of death: Japanese biological warfare, 1932-1945, and the American cover-up. Routledge.

Harris, S. H. (2003). Japanese biomedical experimentation during the World War II era. In D.E. Lounsboury, \& R.F. Bellamy (Eds.), Military Medical Ethics (pp. 463-506). Diane Publishing. 


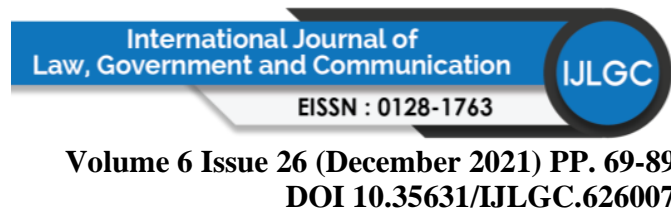

Hill, E. \& Victor, J. (1947). Brucellosis interview with Dr. Kiyoshi Hayakawa, Summary Report of BW Investigations. https://core.ac.uk/download/pdf/145725531.pdf

Ho, F. (2006). The bacteriological institute and its contributions to Hong Kong. In A.E. Starling (Ed.), Plague, SARS and the story of medicine in Hong Kong (pp. 147-176). Hong Kong University Press.

Ichinohe, F. (2016). 15-Nen sensō to Tōhoku teikoku daigaku [The fifteen years war and Tohoku Imperial University]. In K. Nishiyama, K. Karita, \& Y. Wakata (Eds.), Sensō 731 to daigaku ika daigaku [War, 731 and University/Medical Colleges] (pp. 39-71). Tōkyō : Nihon sensō igaku kenkyūkai. http://www.war-medicine-ethics.com /Seniken/Books/war731medicalschools.pdf

Iijima, W. (2016). A hidden history of malaria in 20th century Japan. In \& U. Vögele, Jörg, Koppitz, Ulrich (Ed.), Epidemien und Pandemien in historischer Perspektive/ Epidemics and Pandemics in Historical Perspective (pp. 355-367). Springer Nature. https://doi.org/10.1007/978-3-658-13875-2_26

Iijima, W., Inoue, H., \& Ichikawa, T. (2021). Introducing activities of the archives of infectious diseases history (AIDH) project: Historical epidemiology. Tropical Medicine and Health, 49, 1-9. https://doi.org/10.1186/s41182-020-00296-7

Ika Daigaku being moved to Malacca. (1944, February 5). Syonan Shimbun, 1. https://eresources.nlb.gov.sg/newspapers/Digitised/Article/syonantimes194402051.2 .3

Iwata, M. (1952). Taiheiyō sensō-chū ni okeru Nihon kiseichū Gaku no dōkō [The tendency of research on parasitology in Japan during the Pacific War]. Nara gakugeidagaku kiyō, 1(3), 247-252. http://hdl.handle.net/10105/5183

Kathirithamby-Wells, J. (2005). Nature and nation: Forests and development in Peninsular Malaysia. Nordic Institute of Asian Studies Press.

Keeichi, T. (2010). Unit 731 and the Japanese imperial army's biological warfare program. In J.B. Nie, N. Guo, M. Selden, \& A. Kleinman (Eds.), Japan's wartime medical atrocities: Comparative inquiries in science, history, and ethics (pp. 25-31). Routledge.

Keener, E. (2020). Alternate warfare: The unseen weapons of mass destruction. Liberty University Journal of Statemanship \& Public Policy, 1(1), 1-12. https://digitalcommons.liberty.edu/cgi/viewcontent.cgi?article=1060\&context=jspp

Khoo, S. N., \& Lubis, A.R. (2005). Kinta Valley: Pioneering Malaysia's modern development. Perak Academy.

Kratoska, P. H. (1997). The Japanese occupation of Malaya: A social and economic history. Singapore University Press.

LaCasse, W. J. (1949). Mosquito control problems in Japan. In H.F. Gray, R.F. Peters, \& G.E. Washburn (Eds.), Seventh annual conference of the California Mosquito Control Association held jointly with the annual conference of the American Mosquito Control Association (pp. 10-12). California Mosquito Control Association. https://www.mvcac.org/amg//wp-content/uploads/1949-MVCAC-Volume-17.pdf

Levie, H. S. (1991). Nuclear, chemical, and biological weapons. In H. B. Robertson (Ed.), International law studies- Volume 64 (pp. 331-350). US Naval War College. https://digital-commons.usnwc.edu/cgi/viewcontent.cgi?article $=1759 \&$ context $=$ ils

Li, P. (1999). The Asian-Pacific war, 1931-1945: Japanese atrocities and the quest for postwar reconciliation. East Asia, An International Quarterly, 17(1), 108-137.

Lim, S. B. (2020). Nanpō-gun bōeki kyūsui-bu no kiroku o sagashimotomete [Searching for records of the Southern Army Epidemic Prevention and Water Supply Department]. 15- 


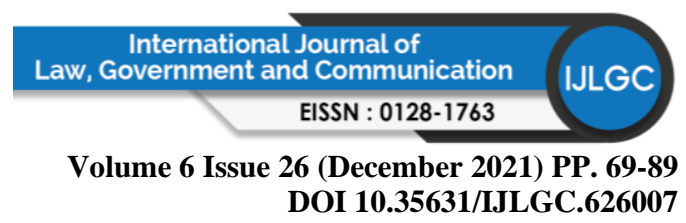

Nen sensō to Nihon no igaku iryō kenkyūkai kaishi, 20(2), 13-30. http://www.warmedicine-ethics.com/Seniken/Journal/J20-2.pdf

Lockwood, J. A. (2009). Six legged soldiers: Using insects as weapons of war. Oxford University Press.

Majid, M. A. (2017). A Japanese biological weapon's legacy in Malaysia: The aftermath effects for environmental contamination, sustainable development and application of international humanitarian law. International Journal of Law, Government and Communication, 2(6), 46-62. http://www.ijlgc.com/PDF/IJLGC-2017-06-12-06.pdf

Manabu Sasa 100 ${ }^{\text {th }}$ anniversary project 笹学100周年プロジェクト. (2006). Sasa-gaku 100shūnen purojekuto [Manabu Sasa 100th anniversary project]. Retrieved from: http://www.sasaseitan100.com/.

Medical research at Kuala Lumpur. (1949, September 30). Coffs Harbour Advocate, 1. https://trove.nla.gov.au/newspaper/article/185058171? searchTerm=medical research at kuala lumpur

Medical research institute under Syonan's control. (1942, November 3). Syonan Shimbun, 2. https://eresources.nlb.gov.sg/newspapers/Digitised/Article/syonantimes194211031.2 .20

Nichigai Associates Co. Ltd. (2004). Kimura Onari (yomi) Kimura Onari [Onari Kimura (reading) Onari Kimura]. In 20 Seiki nihonjin-mei jiten [20th Century Japanese Encyclopedia]. Retrieved from https://kotobank.jp/word/\%E6\%9C\%A8 \%E6\%9D\%91\%20\%E7\%94\%B7\%E4\%B9\%9F-1643625

Nippon doctor to complete research work in Nampo. (1943, October 23). Syonan Shimbun, 1. https://eresources.nlb.gov.sg/newspapers/Digitised/Article/syonantimes194310231.2.17

Nishiyama, K. (2019). "Rusu meibo Kantōgun bōeki kyūsui-bu" "rusu meibo (Shina) kita shina bōeki kyūsui-bu kō dai 1855 butai" "rusu meibo (nanpō) nanpō-gun bōeki kyūsui-bu Oka dai 9420 butai",-chū Shina bōeki kyūsui-bu oyobi minami shina bōeki kyūsui-bu ni kanren suru butai no rusu meibo, "rusu meibo Kantōgun gunba bōeki-shō" kara chūshutsu dekita gun'i shōkō, gishi, gijutsu shōkō, shokutaku, yakuzai shōkō, kangofu, jūi shōkō-tō ["Absence list Kanto Army Epidemic Prevention and Water Supply Department" "Absence list (China) North China Epidemic Prevention and Water Supply Department, Unit A 1855" "Absence List (Southern) Southern Army Epidemic Prevention and Water Supply Department Oka 9420 Unit", Central China Epidemic Prevention and Water Supply Department and South China, The absence list of units related to the Epidemic Prevention and Water Supply Department, military doctor officers, engineers, technical officers, contractors, drug officers, nurses, veterinary officers, etc. extracted from the "Absence List Kanto Army Army Horse Epidemic Prevention Factory"].15-Nen sensō to Nihon no igaku iryō kenkyūkai kaishi, 19(2). http://war-medicine-ethics.com/Seniken/Journal/J19-2.pdf

Ogaki, M. (1949). Bird malaria parasites found in Malay Peninsula. American Journal of Tropical Medicine and Hygiene, s 1-29(4), 459-462.

Osaka Perfecture University. (1983, June). Rénshì: Míngyù jiàoshòu [Personnel: Professor Emeritus]. $\quad \bar{O}$ sakafuritsudaigaku gakubō dai $335-g \bar{o}, \quad 7$. https://core.ac.uk/download/pdf/67687899.pdf

Protocol for the Prohibition of the Use in War of Asphyxiating, Poisonous or Other Gases, and of Bacteriological Methods of Warfare, June 17, 1925, 26 U.S.T. 571, 94 L.N.T.S 65.

Rawlinson, P. (2013). Of mice and men: Violence and human experimentation. State Crime Journal, 2(1), 72-90. 


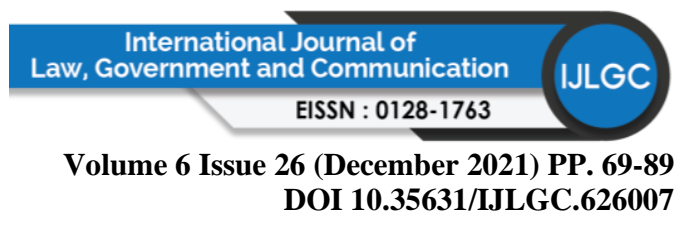

Setoguchi, A. (2006). Igaku kiseichū-gaku konchū-gaku : Nihon ni okeru nettai-byō kenkyū no tenkai [Medicine, parasitology and entomology: The development of tropical disease research in Japan]. Kagaku tetsugaku to kagaku-shi no kenkyū, 1, 125-138. https://repository.kulib.kyoto-u.ac.jp/dspace/bitstream/2433/56971/1/setoguchi.pdf

Setoguchi, A. (2007). Control of insect vectors in the Japanese empire: Transformation of the colonial/metropolitan environment, 1920-1945. East Asian Science, Technology and Society: An International Journal, 1, 167-181. https://doi.org/10.1007/s12280-0079024-3

Shibata, S. (1996). The atomic victims as human guinea pigs. Seisen Review, 4, 1-21. https://core.ac.uk/download/pdf/52039503.pdf

Shinsei Shōnan-jima kaichō no kensetsu [New Shonan Island, good construction]. (1942, February 24). Ōsaka Mainichishinbun, 1-2. http://www.lib.kobeu.ac.jp/das/jsp/ja/ContentViewM.jsp?METAID=00501991\&TYPE=IMAGE_FILE\&P $\mathrm{OS}=1$

Sidhu, H. (1991). The bamboo fortress: True Singapore war stories. Native Publications.

St. Georgiev, V. (2009). Defense against biological weapons (Biodefense). In V. St. Georgiev (Ed.), National Institute of Allergy and Infectious Diseases, NIH (pp. 221-305). Humana Press. https://doi.org/10.1007/978-1-60327-297-1

Stockholm International Peace Research Institute (SIPRI). (1971). The problem of chemical and biological warfare, Volume IV CB disarmament negotiations, 1920-1970. Humanities Press. https://www.sipri.org/sites/default/files/cbw_vol4.pdf

Stockholm International Peace Research Institute (SIPRI). (1973). The problem of chemical and biological warfare, Vol III: $C B W$ and law of war. Humanities Press. https://www.sipri.org/sites/default/files/CBW_VOL3.PDF

Supreme Commander for the Allied Powers, Allied Translator and Interpreter Section (1947). Survey of Japanese medical units (Research Report No. 124). General Headquarters, Supreme Commander for the Allied Powers. https://collections.nlm.nih.gov/ext/dw/14210390R/PDF/14210390R.pdf

The War of the Rebellion: A Compilation of the Official Records of the Union and Confederate Armies (Series III). (1899). Government Printing Office. http://avalon.law.yale.edu/19th_century/lieber.asp

Tohoku University Archives 東北大学史料館. (2007). Kimura kyōju/ Shōwa 12-nen (1937)goro [Professor Kimura /Around 1937]. Retrieved from: http://webdb3.museum.tohoku.ac.jp/tua-photo/photo-img1.php?mode=i\&id=C001506.

Tokyo District Court. (2002, August 27). Extract of the text of the ruling. Retrieved January 2, 2014, from http://www.anti731 saikinsen.net/en/bassui-en.html

Tsuchiya, T. (2005). Japanese medical atrocities 1932-45: What, who, how and why? 22nd International Congress of History of Sciences. http://www.lit.osakacu.ac.jp/user/tsuchiya/gyoseki/presentation/ICHS05.pdf

United States Naval Medical Research Unit No. 2, Guam, Marianas Island. (1946, January 29). War Diary, 12/1-31/45. Retrieved from https://www.fold3.com

US Naval Technical Mission to Japan. (1945). References from the Committee for the Technical and Scientific Survey of Japanese Activities in Medical Sciences. https://collections.nlm.nih.gov/ext/dw/101224189/PDF/101224189.pdf

US Naval Technical Mission to Japan. (1946). Target Report- Pharmacology and malariology in Japan- civilian and naval. https://web.archive.org/web/20120501094124fw_/http://www.fischer- 
Volume 6 Issue 26 (December 2021) PP. 69-89

DOI 10.35631/IJLGC.626007 tropsch.org/primary_documents/gvt_reports/USNAVY/USNTMJ Reports/USNTMJ200C-0690-0811 Report M-12.pdf

Vanderbrook, A. (2013). Imperial Japan's human experiments before and during World War II [Masters thesis, University of Central Florida]. STARS. https://stars.library.ucf.edu /cgi/viewcontent.cgi?referer=https://www.google.com/\&httpsredir=1\&article=3588\& context=etd

Vec, M. (2017). Challenging the laws of war by technology, blazing nationalism and militarism: Debating chemical warfare before and after Ypres, 1899--1925. In B. Friedrich, D. Hoffmann, J. Renn, F. Schmaltz, \& M. Wolf (Eds.), One hundred years of chemical warfare: Research, deployment, consequences (pp. 105-134). Springer International Publishing.

Wiersma, W. (1982). Research methods in education: An introduction (5th edition). Allyn \& Bacon.

Wu, L.T. (1951). Recollections of the early years. In J.W. Field, R. Green \& F.E. Byron (Eds.), Studies from the Institute for Medical Research, Federation of Malaya, Jubilee Volume, No. 25 (pp. 44-87). The Government Press.

Yamauchi, T. (2017). Shimane ken yasukishi shusshin no kiseichū gakusha konchū gakusha, Iwata Masatoshi (1897 - 1997) ni tsuite [On Masatoshi Iwata (1897-1997), a Japanese parasitologist and entomologist from Yasugi, Shimane Prefecture, Japan]. Igaku $\begin{array}{llll}\text { konchü-gakuoyobi dōbutsu-gaku, } & 68(2),\end{array}$ https://www.jstage.jst.go.jp/article/mez/68/2/68_63/_pdf 